\title{
The Inheritance Form of Chinese Traditional Music under College Music Education System
}

\author{
Jing Li \\ College of Art, Yangtze University, Jingzhou, 434000, China
}

\begin{abstract}
In colleges and universities music education system, strengthen the inherit and carry forward the Chinese traditional music, from the point of view of the school, are beneficial to improve college music education quality and effectiveness, to help colleges and universities music education better and the combination of Chinese traditional music teaching, also help colleges and universities music education to fully absorb the cultural charm of Chinese traditional music and national music elements, enrich the college music education content and education resources, and further promote the college music education and the common development of the Chinese traditional music. From the perspective of students, inheriting traditional Chinese music in the music education system in colleges and universities is conducive to enhancing students' profound understanding of the theoretical knowledge of traditional Chinese music, enabling students to better feel the cultural charm and national connotation of traditional music, and solving the problem of disconnection that appeared in the process of students learning music with the development of traditional music culture.
\end{abstract}

Keywords: college music education; Chinese traditional music; inheritance

\section{Introduction}

As an integral part of college education, college music education system should shoulder the burden of inheriting Chinese traditional music and culture, and promote the organic combination of Chinese traditional music and college music education, which is conducive to improve students' correct understanding and cognition of Chinese traditional music.

\section{The Present Situation of Chinese Traditional Music Inheritance under College Music} Education System

From the current situation, under the college music education system, there are still many problems and deficiencies in the inheritance of traditional music in college music education. First, under the background of diversified development of music, there still exists the phenomenon that western music teaching method dominates the classroom in music education in colleges and universities. In the process of education and teaching, music education in many colleges and universities follows the western music teaching concept and teaching mode. In terms of teaching content, it also follows the teaching form of western music to analyze relevant music works and teach students relevant skills. To some extent, this ignores the inheritance of Chinese traditional music in the process of college music education. At the same time, in the current college music education system, piano is still the main course for students majoring in music education, but 
traditional instruments are not introduced into the music education class, which leads to the disconnection between college music education system and the inheritance of traditional Chinese music.

Second, in terms of the cultivation of students, the music education system in colleges and universities mostly uses the music education content and singing mode of western countries, but lacks the education and teaching of the content and singing mode of national music for students. As a result, it is difficult for students to enhance their recognition of traditional Chinese music in the process of music learning. Some students even lack enthusiasm and correct consciousness in learning and inheriting traditional Chinese music. This is not only not conducive to better realize the inheritance and development of Chinese traditional music in college music education, but also not conducive to promote the improvement of students' national literacy and traditional music cultural spirit.

Third, in the current development of music education, the inheritance of traditional Chinese music should not only focus on the concept, but also pay attention to the practice of various forms of traditional Chinese music. At present, music education in colleges and universities still has unreasonable problems in the process of inheriting traditional Chinese music. For example, the theoretical knowledge of music, melody, music score and related music education activities are separated from traditional music to a certain extent, and lack of in-depth analysis and exploration of Chinese traditional music education, too much attention is paid to the study and analysis of western music teaching methods and contents. This situation is not conducive to students to better understand the cultural content and educational knowledge of traditional Chinese music, but also reduces the inheritance effect and quality of traditional Chinese music in the music education system of colleges and universities.

Fourthly, in the process of inheriting the music education in colleges and universities, there still exists the problem that students' learning enthusiasm and initiative are not high. In the process of learning, so pay attention to the contents of the famous western music and vocal music learning, pay attention to the content of western music culture and music expression way of learning, and don't realize the importance and significance of inheriting Chinese traditional music, nor by adopting the combination of Chinese traditional music and western music way effectively contact and inheritance of Chinese traditional music. It is resulted a crisis in the inheritance and development of Chinese traditional music in the music education system of colleges and universities, which is not conducive to the promotion of student music education and the coordinated development of Chinese traditional music.

\section{The Inheritance Strategy of Chinese Traditional Music under College Music Education} System

3.1Strengthening the construction of traditional music curriculum and teaching materials

In order to better realize the inheritance and promotion of traditional music, colleges and universities should establish a correct awareness and concept of the inheritance of traditional Chinese music in the process of music education, and should change the phenomenon that they pay too much attention to the teaching of western music theory and the development of piano, violin and other courses. Meanwhile, in the process of music curriculum construction, teaching courses related to traditional Chinese music should be actively carried out to improve students' correct understanding and recognition of the inheritance and development of traditional Chinese music, so as to better create a good atmosphere for students to inherit traditional music culture. At the same time, we should strengthen the innovation and improvement of college music teaching materials, and fully integrate the content of national songs and national percussion instruments into the compilation of teaching materials. As to Wang Guoan new "primary school music chorus" as an example, in the process of select and compile and create, the most value is the Chinese traditional music and folk songs is blended in among them, the main selection region of Yunnan and Guizhou ethnic percussion, and mainly changeful rhythm, to train 
the students from simple to complex, maximize the realization of the cultivation of the students of Chinese traditional music culture. This kind of teaching form and content is more novel and has a very good inspiration and reference function to the music curriculum education in our country. Therefore, in the course of textbook creation and compilation, we should fully focus on the materials of ethnic music, integrate various forms and contents of ethnic culture, deepen students' experience and feelings of ethnic music, and improve students' correct understanding of Chinese ethnic music. In addition, it is necessary to strengthen the construction of four harmony writing teaching courses when innovating college music courses with the theme of ethnic music elements. In each class, ask students to the content of the first four two chorus singing practice, which in imperceptible to improve students' learning enthusiasm and efficiency of traditional music, help students establish a correct concept of inheritance, and to strengthen the students to the identity of the Chinese traditional music, better help the students with a new perspective to look at China's national music, in order to improve the quality of inheritance of traditional Chinese music.

\subsection{To strengthen the promotion and teaching of ethnic musical instruments}

In the new era, the combination of the music education system in colleges and universities with the inheritance of traditional Chinese music requires us to realize the importance of promoting and teaching ethnic musical instruments, effectively improve students' interest in and learning quality of ethnic musical instruments, and indirectly inherit traditional Chinese music. First of all, colleges and universities should actively add ethnic musical instruments to the elective music education system and the study of the second musical instrument, give full play to the role of ethnic musical instruments in the inheritance of traditional Chinese music, and constantly improve students' traditional music literacy. For example, schools can combine students' learning interests and characteristics to offer courses on ethnic musical instruments such as guzheng, erhu, hulusi and bamboo flute, so as to strengthen students' ability to learn and play ethnic musical nIstruments, make it easier to participate in, and enhance their awareness and concept of traditional music inheritance. Secondly, colleges and universities should actively explore the cultural connotation of ethnic music. They should not only instill the theoretical knowledge of traditional music to students, but also raise students' attention to traditional Chinese music through piano works related to traditional music, so as to constantly enrich the content of music education in colleges and universities. For example, taking the two piano works "yu ge" and "tai chi" created by Zhao Xiaosheng as examples, colleges and universities can integrate piano works related to Chinese elements into the music teaching process, analyze the works and improve students' recognition of traditional Chinese music. Concert tour can be adopted to further promote folk music. Therefore, colleges and universities should actively explore such piano works to promote the inheritance and promotion of traditional Chinese music and folk music.

\subsection{Adopt diversified music teaching methods}

College music education should adopt diversified music teaching methods in order to better realize the inheritance of traditional music. On the one hand, colleges and universities can offer music composition majors, providing students with a platform for creation and practice.In the teaching of music composition, students can effectively train their multi-part singing ability of national songs by using western composition techniques, realize the organic combination of western music and traditional Chinese music, and deepen their understanding of multi-part Chinese works. At the same time, to meet the demand of different level students' learning, teachers should use new media way of collecting related to traditional Chinese music works, strengthen students on the analysis of Chinese works, effective study each ethnic music and cultural characteristics, so that students can take its essence, to inheritance and carry forward the Chinese traditional music. On the other hand, China is a multi-ethnic country, so colleges and universities should use regional characteristics and folk connotation to realize the inheritance of traditional Chinese music. For example, traditional music contains many 
folk songs, songs of labor, hebei clapper opera and other music with ethnic characteristics. Colleges and universities should choose the repertoire and music of traditional ethnic music, combine the music education in colleges and universities with the characteristics of ethnic music, so that students can get in touch with more ethnic music works. In addition, music works related to folk customs, humanities and regional customs can also be shared with students to explain the cultural elements and ethnic characteristics behind the music.

\section{Conclusions}

In a word, under the background of the new situation, music education in colleges and universities should strengthen the promotion of traditional Chinese music. Through the reform of curriculum, teaching methods and teaching content, we can further realize the effective inheritance of folk music and traditional music.

\section{Conflicts of Interest}

The author declares no conflicts of interest regarding the publication of this paper.

\section{References}

[1] Dang Z.Z. (2016). "Finding Music in all Fields" -- An Extension of the Teaching Concept and Content of Traditional Music Courses from the Perspective of Music Education in Colleges and Universities, Journal of Chifeng University (Chinese Philosophy and Social Science Edition), 37(03), 265-269.

[2] Kong D. (2018). Inheritance and Innovation of Chinese Traditional Music from the Perspective of Public Music Education in Colleges and Universities, Art Research, 3, 210-211.

[3] Han X. (2017). On the Important Role of College Music Education in the Inheritance of Traditional National Music Culture, Art Evaluation, 4, 177-179.

[4] Dong C. (2017). A Preliminary Study on the Inheritance of Chinese Traditional Music Culture in the Process of College Music Education, Art Evaluation, 18, 94-96+138. 